\title{
A Syntactic Analysis on Noun Phrase Used in English Song By Ed Sheeran Album
}

\author{
Sri Astia Widia Astuti \\ Pendidikan Bahasa Inggris STKIP Nurul Huda Sukaraja \\ astia199726@gmail.com
}

\begin{abstract}
This study entitles "A Syntactic Analysis on Noun Phrase Used in English Song by Ed Sheeran Album". This study analysis of Noun Phrase by using Jumanto's theory that indicate in his arrangement. This study focused only on the discussion underlined and coding of types of noun phrase. It was found that there are 118 noun phrase im 93 lyrics from the five selected song in the english song lyrics by Ed Sheeran album. There are 92 premodifier or $78 \%, 4$ post modifier or 3,4\%, and 23 premodifier and postmodifier at the same time or $18,6 \%$. The most dominant used of noun phrase in the English song was premodifierthat occurred by 92 data (78\%). The finding of the analysis shows that the English Song by Ed Sheeran Album has all types of Noun Phrase. The arrangement by Jumanto's theory it is easy to provide representation of the noun phrase.
\end{abstract}

Keywords: Syntac, Noun Phrase, Song Lyrics

\section{INTRODUCTION}

Language played an important role in our daily communicated. People in this world used language to communicate each other in order to express their ideas and feeling. Srijono (2017:3) stated that language is a highly organized system in which each unit plays an important part which is related to each other. The people live used language as a tool of communication. There are many things that we can learn about language, such phonology, morphology, syntactic, and semantic. mainly English. Such the researcher knew that English has many part of speech, vocabulary and structure that must understand deeply to construct a good communication or just to create a sentence. Sentence has system formation to make sentence correctly which is called syntax.

There are some previous researchers related to this research. The first, on article from Diana Kusuma Sari of the writer entitles A Syntactic Analysis of Noun Phrase In The Text of Developing English Competencies Book For X Grade of Senior High School. It published on Muhammadiyah University of Surakarta in 2011. It found that there are six constructions of the constituent of Noun Phrase in the text of Developing English Competencies Book for X Grade of Senior High School. Her research analyzed about noun phrase. It is similar with this research that is also about noun phrase. But different with this research is describe English noun phrase found in the text book.

The second, on article from Junaid of the writer entitles A Syntactic Analysis of The English Noun Phrase (A Study at The Fifth Semester of English Department Faculty of Teacher Training and Education University of Muhammadiyah Makassar). It published on University of Muhammadiyah Makassar in 2018. There are similarities and differences between the present studies with Junaid's research. The similarities we can see from study problem about noun phrase. But differences with this research is describe English noun phrase found out by the students of the fifth semester of English Department.

Based on explanation above, Syntax studied how to combine words into bigger linguistics unit of phrases or sentences (Chomsky, 2003:11). It meant syntax is the study of how to arrange English words into an appropriate sentence or it can also be said that syntax is one of aspect that governs the ways in which words combined to phrases. In addition, Prastowo (2009:65) said that phrase is an annexation of two or more words, which obtain a word as a central idea from this annexation, these words made a new explanation of the meaning. 
Dealing with the description above, the researcher interested to analyze the syntax because the researcher ever followed the syntax lectures, in syntax discuss about construction. Construction created some difficulty in understanding that causes insufficient communication. Moreover, the reason why the researcher chosen noun phrase because content much of noun phrase construction that instead became a new meaning which can be analyzed syntactically and the researcher chosen Divide Album by Ed Sheeran to the object of this research because the song are chosen have sweet stories and messages behind which can make this research meaningful to the readers. The researcher hoped the reader can understand deeper about syntactic analysis on noun phrase, especially for those who take grammar and syntax course.

From the statement above, the researcher formulated the research problem as folows: What are the constructions of noun phrase found in English Song in Ed Sheeran's album and has the objectives as follows: to identify of the constructions of noun phrase in English Song by Ed Sheeran's album.

\section{METHODOLOGY}

In this research, the researcher used descriptive method to given clearer description to the problem and give a better understanding about construction of noun phrase to avoid misunderstanding of words. According to Burns and Grove (2003:201), descriptive research "is designed to provide a picture of a situation as it naturally happens" as stated by Moleong (2002: 3) that qualitative methodology is research procedure that produce descriptive data in written or oral words from people and observed act". In other words, this research is Qualitative research because there is no counting in the research.

\section{RESULT AND DISCUSSION}

This part the researcher explain about findings and discussion of the study. The researcher presented and discussion about the analysis of type modifier of lyrics in Ed Sheeran Album (Divide Album) released in 2017. Based on the data in findings, it can be found that there were 118 noun phrase in 93 lyrics with presentage 100\% from five songs in the Divide album by Ed Sheeran. It is consisted of the Premodifier has $78 \%$ or 92 noun phrases, the postmodifier has $3,4 \%$ or 4 noun phrases, and the post-pre modifier has $18,6 \%$ or 23 noun phrases from the total number of the data. Therefore, on the discussion the researcher displayed the construction by Jumanto's theory for syntactic analysis in the song lyrics.

There were 118 noun phrases from the five selected song that representing in the English song by Ed Sheeran album. The presentage for the each noun phrase type of sentence described as follows.

Tabel 1. Percentage of Noun Phrase

\begin{tabular}{|c|l|c|c|}
\hline No & \multicolumn{1}{|c|}{ Type of Noun Phrase } & Frequency & Percentage \\
\hline 1 & Premodifier & 92 & $78 \%$ \\
\hline 2 & Postmodifier & 4 & $3,4 \%$ \\
\hline 3 & Pre-post modifier & 22 & $18,6 \%$ \\
\hline \multicolumn{2}{|c|}{ Total } & 118 & $100 \%$ \\
\hline
\end{tabular}

Based on the table above, the researcher found there are 118 noun phrase of 93 lyrics of 5 songs in the Divide album by Ed Sheeran. Such as from first song there were 21 lyrics, second song there were 23 lyrics, third song there were 17 lyrics, fourth song there were 19 lyrics, and from fifth song there were 13 lyrics. The content of the song consist of Premodifier, Postmodifier, and pre-post modifier both at the same time. 
From the first song it consisted 19 of Premodifier and 7 of pre-post modifier. From the second song it consisted 26 of premodifier and 4 of pre-post modifier. From the third it consisted 16 of premodifier, 2 of postmodifier, and 5 of pre-post modifier. From the fourth song it consisted 15 of premodifier, 1 of postmodifier, and 2 of pre-post modifier. The last from fifth song it consisted 16 of premodifier, 1 postmodifier, and 2 of pre-post modifier.

\begin{tabular}{|c|l|c|}
\hline \multicolumn{2}{|c|}{ Tabel 2. Premodifier } \\
\hline \multirow{2}{*}{1} & \multicolumn{1}{|c|}{ Premodifier } & Head (Noun) \\
\cline { 2 - 2 } & Det.demonstrative & Time \\
\hline \multirow{2}{*}{2} & Our favorite & \multirow{2}{*}{ Song } \\
\cline { 2 - 2 } & Det.possessive + noun & \multirow{2}{*}{ Home } \\
\hline \multirow{2}{*}{3} & Her & Dress \\
\cline { 2 - 2 } & Det.possessive & Don \\
\cline { 2 - 2 } 4 & Det.demonstrative & Drese \\
\cline { 2 - 3 }
\end{tabular}

In table above arrangement noun phrase. Meanwhile, the explaination premodifier as follows:

1) This Time

"This time" indicate as noun phrase because "this time" is a construction which consists by "this" as premodifier (det.article), and "time" as noun (head).

2) Our Favourite Song

3) "Our favourite song" indicate as noun phrase because "our favourite song" is a construction which consists by "our" as premodifier (det.article), "favourite" as premodifier (noun), and "song" as noun (head).

4) Her Home

5) "Her home" indicate as noun phrase because "her home" is a construction which consists by "her" as premodifier (det.possessive) and "home" as noun (head).

6) That Dress

"That dress" indicate as noun phrase because "that dress" is a construction which consists by "that" as premodifier (det.demonstrative), and "dress" as noun (head).

Table 3. Postmodifier

\begin{tabular}{|l|l|c|}
\hline No & Head (Noun) & Galway Girl \\
\hline 1 & \multirow{2}{*}{ Van } & On the jukebox \\
\cline { 3 - 3 } 2 & \multirow{2}{*}{ Acapella } & Prepositional group \\
\cline { 3 - 3 } & & In the bar \\
\hline 1 & \multirow{2}{*}{ Children } & Prepositional group \\
\cline { 3 - 4 } & & Perfect \\
\hline & Head (noun) & Of our own \\
\hline 1 & People & Prepositional group \\
\cline { 3 - 4 } & & What do / Know \\
\hline
\end{tabular}

In table above arrangement noun phrase. Meanwhile, the explaination postmodifier as follows:

1) Van on the Jukebox

"Van on the jukebox" indicate as noun phrase because "van on the jukebox" is a construction which consists by "van" as noun (head) and "on the jukebox" as postmodifier (prepositional grup).

2) Accapella in the Bar 
3) "Acapella in the bar" indicate as noun phrase because "acapella in the bar" is a construction which consists by "acapella" as noun (head) and "in the bar" as postmodifier (prepositional grup).

4) Children of Our Own

5) "Children of our own" indicate as noun phrase because "children of our own" is a construction which consists by "children" as noun (head) and "of our own" as postmodifier (prepositional grup).

6) People marching in the streets today

"People marching in the streets today" indicate as noun phrase because "People marching in the streets today" is a construction which consists by "people" as noun (head), "marching in the streets" as postmodifier ( $v$-ing grup), and "today" as postmodifier (adverb).

Table 4. Premodifier-Head-Postmodifier

\begin{tabular}{|c|c|c|c|}
\hline No & Premodifier & Head & Postmodifier \\
\hline \multirow{2}{*}{1} & The sweet & \multirow{2}{*}{ Parfum } & Of the mountain grass \\
\hline & Det.article + adj & & Prepositional group \\
\hline \multirow{2}{*}{2} & The roaring & \multirow{2}{*}{ Fields } & In so long \\
\hline & Det.article + & & Prepositional group \\
\hline \multirow{2}{*}{3} & The & \multirow{2}{*}{ Castle } & On the hill \\
\hline & Det.article & & Prepositional group \\
\hline \multirow{2}{*}{4} & My first & \multirow{2}{*}{ Kiss } & On a Friday night \\
\hline & Det.possessive+num & & Prepositional group \\
\hline \multirow{2}{*}{5} & One & \multirow{2}{*}{ Brother } & Overdosed \\
\hline & Det.numerical & & V-ed \\
\hline
\end{tabular}

In table above arrangement noun phrase. Meanwhile, the explaination pre-post modifier as follows:

1) The Sweet Parfum Of The Mountain Grass

"The Sweet Parfum Of The Mountain Grass" indicate as noun phrase because "The Sweet Parfum Of The Mountain Grass" is a construction which consists by "the" as premodifier (det.article), "sweet" as premodifier (adjective), "parfum" as noun (head) and "of the mountain grass" as postmodifier (prepositional grup).

2) The Roaring Fields In So Long

"The Roaring Fields In So Long" indicate as noun phrase because "The Roaring Fields In So Long" is a construction which consists by "the" as premodifier (det.article), "roaring" as premodifier (v-ing), "fields" as noun (head) and "in so long" as postmodifier (prepositional grup).

3) The Castle On The Hill

"The castle on the hill" indicate as noun phrase because "the castle on the hill" is a construction which consists by "the" as premodifier (det.article), "castle" as noun (head) and "on the hill" as postmodifier (prepositional grup).

4) My First Kiss On A Friday Night

"My first kiss on a Friday night" indicate as noun phrase because "my first kiss on a Friday night" is a construction which consists by "my" as premodifier (det.possessive), "first" as premodifier (det.numerical), "kiss" as noun (head) and "on a Friday night" as postmodifier (prepositional grup).

5) One Brother Overdosed

"One brother overdosed" indicate as noun phrase because "one brother overdosed" is a construction which consists by "one" as premodifier (det.numerical), "brother" as noun (head) and "overdosed" as postmodifier ( $v$-ed). 
56 Channing: English Language Education and Literature Vol. 5 No. 2 Oktober 2020 Halaman: 52-56

\section{CONCLUSION}

Consern to findings and discussions above, the researcher concluded that the result of analyzing English song, as follows:

First, it can be inferred that English song (Divide album by Ed Sheeran) has all types of noun phrase. The lyrics using variety of noun phrase types in order to make it interesting to the study, such as premodifier, postmodifier, and premodifier and postmodifier at the same time.

Second, from the data and the analysis found by the researcher about noun phrase on the English song, from 118 data noun phrase in 93 lyrics, there are 92 premodifier or $78 \%, 4$ post modifier or $3,4 \%$, and 23 premodifier and postmodifier at the same time or $18,6 \%$. The most dominant used of noun phrase in the English song was premodifier that occurred by 92 data $(78 \%)$.

\section{REFERENCIES}

Burn,SN and Grove, SK. (2003). Understanding Nursing Research. Philadelphia: Saunders.

Chomsky, Noam. (2002).Syntactic Structures. Berlin: Mouton de Gruyter.

Diana, K.S, Malikatul Laila, \& Nur, Hidayat. (2012). A Syntactic Analysis of Noun Phrase In The Text of Developing English Competencies Book For X Grade of Senior High School. Article. Muhammadiyah University of Surakarta.

Junaid. (2018). A Syntactic Analysis of The English Noun Phrase (A Study at The Fifth Semester of English Department Faculty of Teacher Training and Education University of Muhammadiyah Makassar). Article. University of Muhammadiyah Makassar.

Moleong. Lexy, J. (2002). Metodologi Penelitian Kualitatif. Bandung: PT Remaja Rosdakarya.

Prastowo, P. (2009). Pintar Mengolah Kalimat (sentence) Bahasa Inggris. Jogjakarta: Tunas Publishing. 